УДК 616.151.5-02:616-008.93:577.161.5]008.64

\author{
В.В. Войцеховский, Т.В. Заболотских, \\ С.С. Целуйко
}

ФГБОУ ВО Амурская ГМА Минздрава России

г. Благовещенск

\section{ПРИОБРЕТЕННЫЕ КОАГУЛОПАТИИ,} ОБУСЛОВЛЕННЫЕ ДЕФИЦИТОМ

К-ВИТАМИНЗАВИСИМЫХ ФАКТОРОВ СВЕРТЫВАНИЯ КРОВИ

В 1929 г. датский учёный Carl Peter Henrik Dam исследовал последствия недостатка холестерина у цыплят, находившихся на лишённой холестерина диете. Через несколько недель у цыплят развился геморрагический синдром кровоизлияние в подкожную клетчатку, мышцы и другие ткани. Добавление очищенного холестерина не устраняло патологических явлений. Оказалось, что целебным эффектом обладают зёрна злаков и другие растительные продукты. Наряду с холестерином из продуктов были выделены вещества, которые способствовали повышению свертывания крови. За этой группой витаминов закрепилось название «витамины К», поскольку первое сообщение об этих соединениях было сделано в немецком журнале, где они назывались Koagulations vitamin (витамины коагуляции). В 1939 г. в лаборатории швейцарского ученого Каррера впервые был выделен из люцерны витамин К, его назвали филлохиноном. В том же году американские биохимики Бинклей и Дойзи получили из гниющей рыбной муки вещество с антигеморрагическим действием, но с иными свойствами, чем препарат, выделенный из люцерны. Это вещество получило название витамин К в отличие от витамина из люцерны, названного витамином $\mathrm{K}_{1}$.

Витамин К относится к группе липофильных (жирорастворимых) и гидрофобных витаминов, необходимых для синтеза белков, обеспечивающих достаточный уровень коагуляции. Химически является производным 2-метил-1,4-нафтохинона. Играет значительную роль в обмене веществ в костях и в соединительной ткани, а также в нормальной работе почек. Во всех этих случаях витамин участвует в усвоении кальция и в обеспечении взаимодействия кальция и витамина D. B других тканях, например, в лёгких и в сердце, тоже были обнаружены белковые структуры, которые могут быть синтезированы только с участием витамина К. Витамин К - это групповое название для ряда производных 2-метил-1,4-нафтохинона, сходного строения и близкой функции в организме. Обычно они имеют

Резюме В публикации представлена информация о наиболее распространенных приобретенных коагулопатиях, обусловленных дефицитом К-витаминзависимых факторов свертывания крови. Освещены возможности современной терапии этой патологии.

Ключевые слова: К-витаминзависимые факторы гемостаза, коагулопатия. метилированный нафтохиноновый фрагмент с переменной по числу звеньев алифатической боковой цепью. Филлохинон (так же именуемый витамином $\mathrm{K}_{1}$ ) содержит 4 изопреноидных звена, одно из которых является ненасыщенным. В природе найдены только два витамина группы К: выделенный из люцерны витамин К и выделенный из гниющей рыбной муки К $\mathrm{K}_{2}$ Кроме природных витаминов К, в настоящее время известен ряд производных нафтохинона, обладающих антигеморрагическим действием, которые получены синтетическим путем. К их числу относятся следующие соединения: витамин $\mathrm{K}_{3}$ (2-метил-1,4-нафтохинон), витамин К (2-метил-1,4-нафтогидрохинон), витамин $\mathrm{K}_{5}^{4}$ (2-метил-4-амино-1-нафтогидрохинон), витамин $\mathrm{K}_{6}$ (2-метил-1,4-диаминонафтохинон), витамин $\mathrm{K}_{7}^{6}$ (3-метил-4-амино-1-нафтогидрохинон).

Витамин К участвует в карбоксилировании остатков глутаминовой кислоты в полипептидных цепях некоторых белков. В результате такого ферментативного процесса происходит превращение остатков глутаминовой кислоты в остатки гамма-карбоксилглутаминовой кислоты (сокращенно Gla-радикалы). Остатки гамма-карбоксилглутаминовой кислоты (Gla-радикалы), благодаря двум свободным карбоксильным группам участвуют в связывании кальция. Gla-радикалы играют важную роль в биологической активности вcex известных Gla-белков. B настоящее время обнаружены 14 человеческих Gla-белков, играющих ключевые роли в регулировании следующих физиологических процессов: свёртывание крови - протромбин (фактор II), факторы VII, IX, X, белок C, белок S и белок Z); метаболизм костей (остеокальцин, так же названный Gla-белком кости, и матрицей gla белка (MGP).

Причины развития дефицита витамина К [2]: нарушения обмена; нарушения синтеза; недостаточное поступление с пищей; действие препаратов, связывающих желчные кислоты; заболевания желчных путей, препятствующие адсорбции жирорастворимых витаминов; заболевания кишечника, сопровождающиеся нарушением всасывания витамина К; выработка ингибиторов к факторам свертывания крови; заболевания печени; ДВС-синдром; прием антикоагулянтов непрямого действия; отравление родентицидами, содержащими непрямые антикоагулянты. Наиболее частой причиной коагулопатии, обусловленной дефицитом К-витаминзависимых факторов свертывания крови, является передозировка антикоагулянтов непрямого действия, которые сейчас активно используются в клинической практике.

\section{Передозировка антикоагулянтов непрямого действия}

В начале 20-х годов XX века была зарегистрирована вспышка ранее неизвестных заболеваний коров в северных территориях США и в Канаде. Канадский ветеринар Frank Schofield экспериментально установил связь геморрагических проявлений с поеданием животными плесневелого силоса из донника (сладкого клевера). Десятью годами позже ветеринар Lee Roderick объяснил причину кровотечений у животных с так называемой «болезнью сладкого клевера» 
недостаточностью одного из факторов свертывающей системы крови - протромбина. Одновременно с этими исследованиями датский биохимик и физиолог Henrik Dam, изучая биохимические свойства витаминов и стеролов (19291935), обратил внимание на то, что клинические проявления «болезни сладкого клевера» очень схожи с геморрагическим диатезом цыплят. Он обнаружил, что поражения кожи и мышц у птиц, находящихся на синтетической диете, связаны с отсутствием в их рационе жирорастворимого вещества, которое в 1935 году назвали витамином K (koagulations vitamin) (Quick A.J., 1937). Потребовалось длительное время (1933 - 1939) прежде, чем сотрудник научной лаборатории под руководством Karl Link Harold Campbell получил кристаллы дикумарола.

Дикумарол был продуктом растительных молекул кумарина. Кумарин присутствует во многих растениях и производит сладкий запах свежескошенной травы или сена, а также некоторых растений, например, Зубровки душистой. Сам по себе кумарин не влияет на свёртывание крови, но может быть вначале метаболизирован различными грибами в соединения, такие, как 4-гидроксикумарин, а далее (в присутствии естественного формальдегида) - в дикумарол, который обладает антикоагулянтными свойствами. Повреждение и гибель стеблей клевера под воздействием грибов объясняет наличие антикоагулянта только в испорченном силосе клевера. Дикумарол считается продуктом брожения и микотоксином [22].

В течение следующих нескольких лет у многочисленных аналогичных веществ (например, 4-гидроксикумарины) обнаруживали те же антикоагулянтные свойства. Первым лекарственным препаратом из класса непрямых антикоагулянтов был, собственно, дикумарол, запатентованный в 1941 году и затем применявшийся как фармакологическое средство. Karl Link продолжил работы над созданием более мощных кумарин-подобных антикоагулянтов для использования в качестве яда для грызунов, в результате чего в 1948 году был синтезирован варфарин. Название «варфарин» (англ. warfarin) происходит от аббревиатуры WARF (англ. Wisconsin Alumni Research Foundation) + окончания -arin, указывающего на связь с кумарином. Варфарин

\section{ACQUIRED COAGULOPATHY CAUSED BY THE DEFICIENCY OF K-VITAMIN-DEPENDENT FACTORS OF BLOOD COAGULATION}

V.V. Voytsekhovskiy, T.V. Zabolotskikh, S.S. Tseluyko

FSBEI HE the Amur state medical Academy of the Ministry of Public Health of Russia, Blagoveshchensk

Abstract The publication provides information on the most common acquired coagulopathies caused by a deficiency of K-vitamin-dependent blood coagulation factors. The possibilities of modern therapy of this pathology are highlighted.

Key words: K-vitamin-dependent blood coagulation factors, coagulopathy.

\section{DOI 10.22448/AMJ.2019.1.59-71}
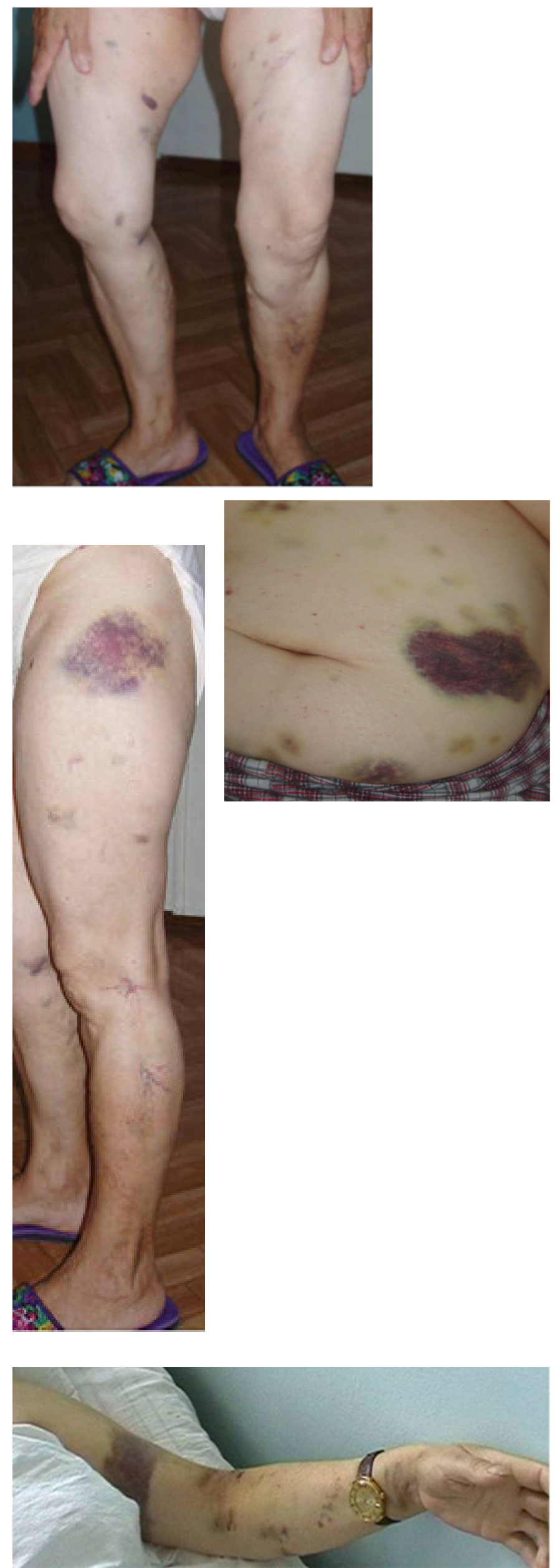

Рисунок 1. Геморрагический синдром при передозировке варфарина. 
был зарегистрирован как яд для грызунов в США в 1948 году и сразу же получил широкое распространение [39].

После того, как в 1951 году призывник армии США безуспешно попытался покончить жизнь самоубийством, приняв несколько доз варфарина в составе яда для грызунов и полностью выздоровел в госпитале, где ему вводили витамин К (уже тогда известный как специфический антидот), были начаты исследования по применению варфарина в качестве терапевтического антикоагулянта [39]. Было обнаружено, что варфарин превосходит по эффективности дикумарол, в 1954 г. он был одобрен для медицинского использования у людей.

Сегодня варфарин как крысиный яд используют реже, так как у многих популяций крыс развилась устойчивость к нему и стали доступны более эффективные яды хронического действия, так называемые «суперварфарины» - бродифакум, бромадиолон, флокумафен, дифетиалон и дифенакум [16]. В то же время варфарин как непрямой антикоагулянт нашел широкое применение в клинической практике.

Различают антикоагулянты прямого и непрямого действия. Первые влияют непосредственно на факторы свертывания, находящиеся в крови, и понижают активность тромбина в крови; к ним относится гепарин, который бывает нефракционированным и фракционированным (низкомолекулярным). Антикоагулянты непрямого действия нарушают биосинтез протромбина, проконвертина и других факторов свертывания в печени. В отличие от антикоагулянтов прямого действия антикоагулянты непрямого действия оказывают эффект не сразу, они действуют медленно и продолжительно, обладают кумулятивными свойствами.

Дикумарол был первым и основным представителем антикоагулянтов непрямого действия группы 4-оксикумарина. Отечественный аналог дикумарола - дикумарин - был синтезирован в 1946 г. в Уральском филиале ВНИХФИ И.Я. Постовским и М.А. Панюковой. Однако в связи с высокой токсичностью данные препараты были постепенно заменены другими непрямыми антикоагулянтами, производными кумарина, такими, как неодикумарин, фепромарон, нитрофарин, синкумар, варфарин.

По химической структуре антикоагулянты непрямого действия (АНД) разделяются на три подгруппы [3]:

- производные монокумарина (варфарин, аценокумарол);

- кумарина (этил бискумацетат);

- индандиона (фениндион).

Профилактику антикоагулянтами непрямого действия (АНД) и терапию тромбозов стали широко использовать в клинике с начала 50-х годов прошлого столетия. В СССР инициаторами применения АНД были Б.В. Кушелевский, П.Е. Лукомский и Е.И. Чазов. Однако впоследствии интерес к данной группе препаратов существен- но снизился. Объяснялось это с одной стороны широким внедрением в практику антикоагулянтов прямого действия, а с другой - недостаточно полноценным лабораторным контролем за действием АНД и неотработанностью оптимальных доз препаратов, что приводило к развитию большого числа геморрагических осложнений [1]. В последнее время в связи с необходимостью проведения многолетней антикоагуляционной терапии и разработкой новой эффективной методологии мониторинга дозировок АНД интерес к лечебно-профилактическому применению АНД снова вырос, особенно с появлением на российском фармацевтическом рынке одного из лучших препаратов указанной группы - варфарина $[1,14,15]$.

Когда больной принимает варфарин, плазменные уровни протромбина и факторов VII, IX и X, формируемых печенью, начинают падать, свидетельствуя, что варфарин имеет мощное действие, подавляющее синтез этих соединений печенью. При применении этого препарата блокируется так же синтез двух физиологических антикоагулянтов - белков С и S. Варфарин вызывает этот эффект, конкурируя с витамином К за реактивные участки в ферментативных процессах при формировании протромбина и других трех факторов свертывания, блокируя действие витамина К. Витамин К необходим на конечном этапе образования вышеуказанных факторов свертывания - на фазе карбоксилирования. Присутствие карбоксильной группы обеспечивает связывание указанных факторов с кальцием, а через кальций - с фосфолипидами и фактором Ха, что является необходимым условием трансформации протромбина в тромбин. При отсутствии витамина К в кровоток поступают незавершенные, лишенные возможности взаимодействовать с ионами кальция и участвовать в свертывании крови предшественники витамин К-зависимых факторов. При начале приема варфарина процесс свертывания не блокируется немедленно, поскольку прежде должен произойти естественный расход уже присутствующих в плазме протромбина и других факторов свертывания, на которые действует варфарин. Максимальное действие препарата проявляется на 3-5-й день от начала применения и прекращается через 3-5 дней после отмены. При этом депрессия синтеза факторов при К-гиповитаминозе возникает не одновременно, а последовательно, что зависит от продолжительности их жизни в циркуляции: в первую очередь происходит снижение активности фактора VII (период полужизни - 4 часа), затем уменьшается активность факторов IX и X, в последнюю очередь снижается активность протромбина (через 3-4 дня). В том же порядке происходит и восстановление уровня прокоагулянтов после устранения дефицита витамина К.

Аценокумарол уступает варфарину по эффективности и безопасности [3]. Производные индандиона обладают подобным кумаринам антикоагулянтным действием, но чаще вызывают побочные эффекты - токсическое влияние на печень, кожные проявления. Поэтому производные индандиона назначаются больным, имеющим аллергические реакции на производные кумарина [3]. 

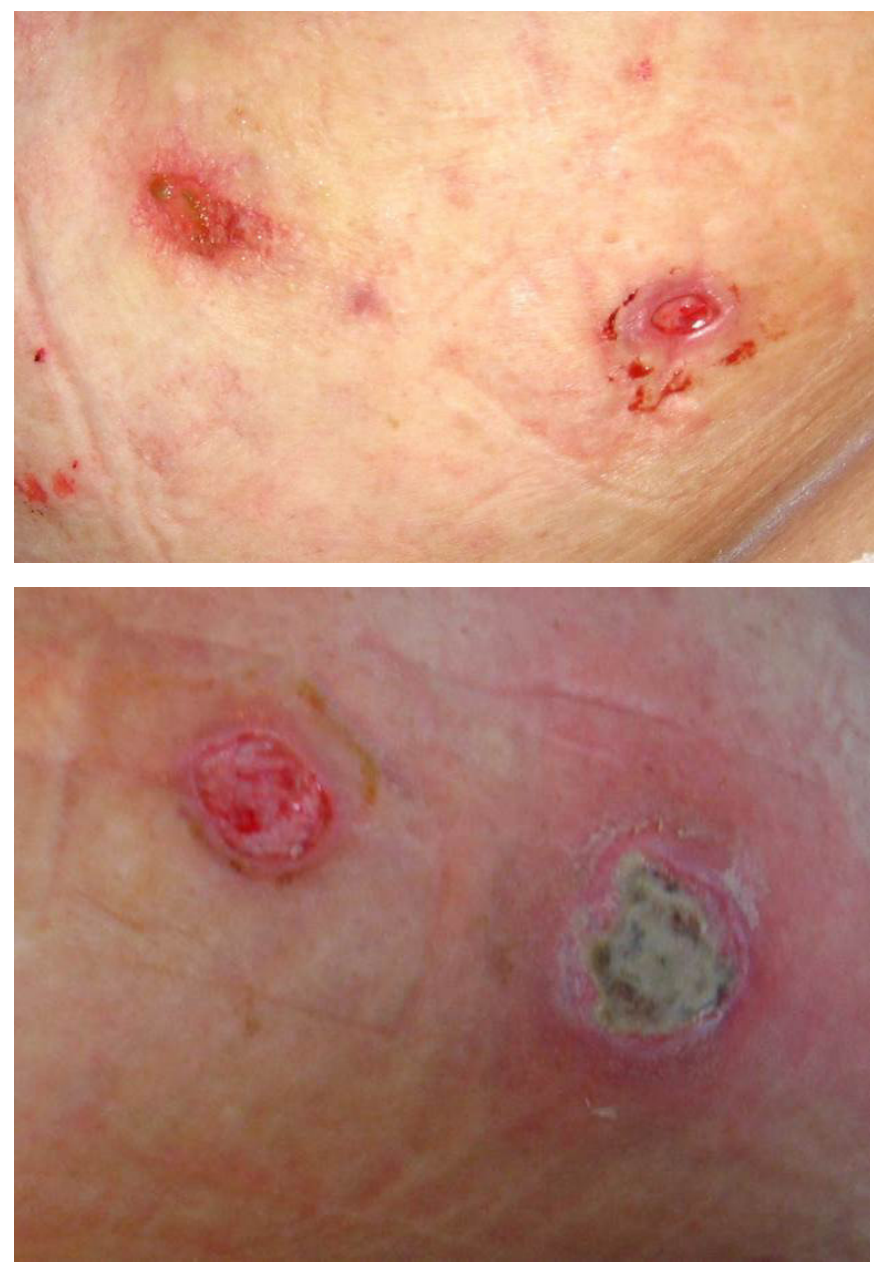

Рисунок 2. Варфариновый некроз кожи.

Начальная доза варфарина, как правило, составляет 5 мг/сут. (2 таблетки). Дальнейший режим дозирования устанавливают индивидуально, в зависимости от результатов определения протромбинового времени и/или международного нормализованного отношения (МНO). Протромбиновое время при приеме варфарина должно быть увеличено в 2-4 раза от исходного, а $\mathrm{MHO}$ в большинстве случаев должно достигать 2-3. У стариков, онкологических больных и в ряде других ситуаций МНО в процессе лечения варфарином должно быть несколько меньшим $(1,4-2,0)[1,3,19]$. Если пациент одновременно с варфарином принимает дезагреганты, уровень MHO должен быть 1,8 - 2,2 [1, 3].

Варфарин противопоказан в первой трети беременности, поскольку высок риск развития врожденных дефектов плода, при тяжелых поражениях печени (гепатиты и циррозы), в течение 6 месяцев после перенесенного геморрагического инсульта, при различных кровотечениях. Не рекомендуется назначение варфарина пациентам с гематогенными тромбофилиями, обусловленными дефицитом физиологических антикоагулянтов, - протеинов C и S. Вследствие дальнейшего угнетения непрямыми антикоагулянтами дефицитных протеинов C и S развивается гиперкоагуляционный синдром и так называемый «синдром рикошета», когда несмотря на прием варфарина и увеличение его дозы тромбообразоваение прогрессирует [2].
В последнее десятилетие варфарин практически вытеснил из применения в медицинской практике все другие АНД. Однако в процессе применения этого препарата определился и ряд его недостатков. В первую очередь это необходимость частого лабораторного контроля в связи с высоким риском развития геморрагического синдрома (кровотечения, кровоизлияния) (рис. 1). Ввиду особенностей некоторых регионов Российской Федерации - низкой плотности населения на больших территориях, значительной отдаленности ряда населенных пунктов от медицинских центров и т.д., во многих районах нет возможности не только контролировать МНО, но и систематически наблюдать пациента. Другие, реже встречающиеся осложнения терапии варфарином, - диарея, повышение активности печеночных трансаминаз, остеопороз, экзема, некроз кожи, васкулиты, алопеция [1, 3, 17]. У части больных отмечается генетически обусловленная высокая резистентность к кумаринам, эту патологию связывают с нарушением в печени сродства клеточных рецепторов к кумаринам $[1,2]$.

Варфариновый некроз кожи - редкое, но серьёзное осложнение в результате лечения варфарином. Развитие некроза кожи возможно так же при лечении любым препаратом из группы кумаринов. Варфариновый некроз кожи в большинстве случаев развивается у женщин, чаще примерно на третьи - десятые сутки со дня начала терапии непрямыми антикоагулянтами. Развитие данного осложнения начинается с возникновения красных бляшек достаточно плотной структуры. Данным бляшкам присущи весьма четкие границы, которые уже через несколько часов приобретают фиолетовый либо черный оттенок. На пораженных участках выступают пузыри, которые со временем переходят в язвы и струпья (рис. 2). Избавиться от данного рода поражений не так уж просто. Если варфариновый некроз успел развиться, отмена медикамента уже не сыграет никакой роли. Возникнуть это осложнение может на кожном покрове бедер, молочных желез, ягодиц и других местах наибольшего отложения жира. Дозировка варфарина не имеет совершенно никакого значения. В данном случае особую роль играет количество протеина С в организме человека. Так как варфарин уменьшает уровень физиологического антикоагулянта - протеина С - быстрее, чем факторов свёртывания крови, то в начале лечения возможно парадоксальное увеличение свёртывающих свойств крови (для предупреждения этого многие пациенты в начале лечения варфарином так же получают гепарин). Поэтому возможно возникновение массивных тромбозов с некрозом кожи и гангреной конечностей $[3,6,23]$. В данной ситуации пациенты переводятся на прямые антикоагулянты, в тяжелых случаях назначаются трансфузии свежезамороженной плазмы и препараты витамина К. Последнее время при дефиците протеина С используется его фармакологический препарат сепротин. Сходную клиническую картину наблюдают при гепариновом некрозе кожи, который, видимо, обусловлен окклюзией мелких сосудов в результате повышенной агрегации тромбоцитов [3]. 
В связи с вышеизложенным, в последнее время активно идет поиск альтернативных препаратов для проведения вторичной профилактики тромбозов у пациентов, которым по каким-либо причинам противопоказан варфарин. Применение парентеральных антикоагулянтов с целью профилактики тромбообразования довольно обременительно для больного и часто заканчивается низкой приверженностью к лечению. Варфарин в последнее время активно заменяют прямые оральные антикоагулянты - прямой ингибитор тромбина дабигатран и прямые ингибиторы фактора Ха - ривароксабан и апиксабан, вызывающие меньшее количество осложнений и не требующие столь частого контроля коагулограммы. Варфарин в настоящее время является препаратом выбора только у больных с искусственными клапанами сердца и при ряде других кардиохирургических вмешательств.

\section{Профилактика и лечение кровотечений при приеме АНД}

Частой причиной неправильного дозирования варфарина, как и других лекарственных препаратов, является забывчивость больных, вследствие чего они либо пропускают очередной прием препарата, и тогда МНО снижается, либо принимают дополнительно лишнюю дозу его, запамятовав, что ранее уже приняли таблетку препарата [1, 2, 43]. Во избежание таких ошибок следует рекомендовать больному заранее расфасовывать таблетки по коробочкам, имеющим маркировку по дням недели $[1,2]$. Риск геморрагий неуклонно возрастает по мере увеличение MHO: при цифрах менее 2,5 они крайне редки, при уровне от 2,5 до 3,0 - редки и обычно минимальны. Поэтому цель мониторирования - поддерживать МHO ниже 3,0 - 3,5. При превышении этих цифр доза варфарина должна быть снижена и контроль за уровнем МНО учащен, а больные более тщательно проверяться на наличие симптомов кровоточивости и эритроцитов в моче.

При снижении МНО ниже намеченного уровня прибегают к дробному назначению дополнительных доз варфарина. Целесообразно ступенеобразное повышение дозы - например, по 1/4 таблетки, т.е., по 0,12 мг ежедневно (при очень низком МНO) или через день - до достижения необходимого параметра этого индекса.

При повышении МНО до 4,0 - 4,5 и в случае отсутствия каких-либо геморрагических проявлений, делают перерыв в приеме варфарина под контролем ПТ на 1-2 дня до возврата МНО к нужному уровню.

При повышении МНО более 5,0, одновременно с временной отменой варфарина назначают прием внутрь или в инъекциях препарат витамина К по 1-2 мг/сут. - до снижения МНО к необходимому терапевтическому уровню. Часто для этого достаточен однократный прием внутрь 1,0 мг витамина К [21].

Если при повышенных цифрах МНО у больного отмечаются серьезные геморрагические проявления (рис. 1), он подлежит немедленной временной госпитализации, отмене приема варфарина, введению внутривенно или внутрь витамина К. При больших кровотечениях выполняются так же трансфузии свежезамороженной плазмы по 500 - 800 мл/сут.

При кровотечениях, вызванных варфарином при невысоком МНО (около 3,5), следует думать либо о наличии аномалии фактора IX, либо о нераспознанном другом заболевании, предрасполагающем к кровотечениям (язвенная болезнь, эрозивный гастрит и др.). Аномалия фактора IX легко подтверждается или, наоборот, исключается определением АПТВ. В этом случае для купирования кровотечений необходимы трансфузии свежезамороженной плазмы (не менее 800 мл в первый день и по 500 мл в последующие дни до момента нормализации АПТВ). Еще более эффективны при такой ситуации внутривенные введения очищенных фирменных концентратов фактора IX. При кровотечениях, обусловленных не выявленными ранее болезнями желудка и кишечника, наряду с временной отменой варфарина проводят соответствующую патогенетическую терапию этих заболеваний, назначают прием внутрь или в виде локальных орошений аминокапроновой кислотой.

В целом нужно отметить, что при правильно организованном лабораторном контроле геморрагические осложнения крайне редки при длительном приеме кумаринов и поддержании МНО ниже 3,0 и в большинстве своем ограничиваются минимальными или малыми проявлениями.

При больших передозировках АНД быстрое купирование кровотечений может быть достигнуто внутривенным введением свежезамороженной плазмы, препаратов протромплекс или рекомбинантного VIla фактора в средних терапевтических дозах [2, 29; 31].

3.С. Баркаган (2005) отмечал, что сотрудники руководимой им клиники часто сталкиваются с «наведенной» кумариновой кровоточивостью, которая в подавляющем большинстве случаев быстро купируется парентеральным введением препаратов витамина К, трансфузиями свежезамороженной плазмы и/или введением концентратов факторов протромбинового комплекса. Причинами «наведенной» кумариновой кровоточивости являются скрытый прием больными с истерией и другими психическими расстройствами антикоагулянтов непрямого действия; случайный прием кумаринов вместо других лекарственных средств; старческая амнезия (при нарушении памяти и избыточном приеме антикоагулянтов непрямого действия); добавление в пищу значительных доз кумаринов или крысиного яда с целью убийства или самоубийства; случайные попадания в рот или в пищу веществ, содержащих кумарины или крысиный яд; прием с пищей кумаринов молодыми людьми призывного возраста с целью провокации геморрагического синдрома для освобождения их от службы в армии; при лечении и самолечении травами, в состав которых входит сладкий клевер [2].

\section{Отравление суперварфаринами}

Применение родентицидов (РДЦ) (от лат. rodents, род. падеж rodent is - грызущий и caedo - убиваю) - пестицидов из группы зооцидов - яв- 
ляется наиболее эффективным химическим способом борьбы с грызунами. Для уничтожения грызунов используются разнообразные химикаты к которым относятся фосфид алюминия и фосфид цинка, мышьяк, таллий, стрихнин, карбонат бария, непрямые антикоагулянты [18]. В настоящее время наибольшее распространение получили РДЦ классов 1,3-индандионов и 4-гидроксикумаринов, обладающие антикоагулянтным механизмом действия и избирательностью в отношении целевых видов животных. Отравление РДЦ встречается гораздо реже, чем отравления другими токсическими веществами, однако количество таких случаев постоянно растет $[40,41,50,52,53]$. В зарубежной литературе встречается много работ, посвященных отравлению РДЦ, обладающими антикоагулянтными свойствами. Отмечается, что установить диагноз (причину коагулопатии) часто бывает непросто, т.к. пациенты либо скрывают употребление препарата, либо не придают его случайному воздействию большого значения [37, 33]. Chua J.D. and Friedenberg W.R. отмечают, что в США в 1988 году зарегистрировано 5133 случаев воздействия и отравлений суперварфаринами, в 1995 году - 13423; их причины: случайный прием, попытки самоубийства, психические расстройства (синдром Мюнхгаузена). По данным Watson W.A. et al., в США в 2004 году было отмечено более 16 тысяч случаев отравлений РДЦ, из них 15000 случаев - у детей.

Различают РДЦ острого и хронического действия. В настоящее время на территории Российской Федерации разрешены к применению РДЦ острого действия: фосфид цинка и 1-нафтилтиомочевина (крысид), рекомендованные для включения в рецептуры различных РДЦ-средств [16].

Большинство современных РДЦ хронического действия являются непрямыми антикоагулянтами. Как правило, они не растворимы в воде, но растворяются в органических растворителях; сохраняют свои токсические свойства в течение нескольких лет; обладают резко выраженными кумулятивными свойствами. Для РДЦ характерно сравнительно длительное развитие процесса отравления, способность в малых количествах аккумулироваться в организме зверьков до летальных доз. Механизм действия большинства РДЦ заключается в ингибировании витамина K, который участвует в процессе синтеза факторов свертывания. Типичное время начала развития клинических симптомов варьирует от 3 до 5 дней от попадания РДЦ в организм. Это обусловлено наличием в организме собственных запасов витамина K, необходимых для синтеза факторов свертывания. Постепенное прекращение синтеза собственного витамина К приводит к развитию тяжелого геморрагического синдрома, который и является причиной гибели грызуHOB.

Концентрации действующего вещества (ДВ) в приманках столь малы, что у животных не возникает оборонительной реакции на приманку. Использование этих ядов позволяет раскладывать крупные порции приманок для уничтожения всех обитающих зверьков, создавать "точки долговременного отравления» [16].

Антикоагулянты 1 поколения (варфариновые РДЦ) действуют медленно (гибель грызунов затягивается до месяца) и требуют серии повторных обработок (от 3 до 6 раз). Сроки дератизации при этом затягиваются до 15-20 дней, иногда до месяца.

Антикоагулянты 2 поколения - суперварфарины (бродифакум, бромадиолон, флокумафен, дифетиалон и дифенакум) действуют быстрее: гибель зверьков наступает через 4-10 дней при однократном поедании приманки. ДВ этих родентицидов относятся к 1-му классу опасности. [16]. Суперварфарины были предложены для борьбы с грызунами, устойчивыми к действию варфарина. В отличие от варфарина, который легко выделяется из организма, суперварфарины накапливаются в печени и почках после их употребления.

Родентицидные средства антикоагулянтного действия выпускаются в виде концентратов (порошки, пасты, гели и растворы), а также готовых приманок с нейтральными наполнителями. В целях распознавания ядовитых приманок их окрашивают в различные цвета. Во избежание случайного отравления людей и домашних животных в концентраты и приманки с антикоагулянтами 2 поколения добавляется горечь (битрекс). Расход приманочных продуктов при использовании антикоагулянтов в несколько раз превышает расход с ядами острого действия.

На разных этапах приготовления и применения РДЦ-средств возможен контакт работающих и населения с действующими веществами и готовыми препаративными формами на их осноBe.

В.И. Денисенко (2008) провел гигиеническую и токсикологическую оценку препаратов на основе бромадиолона и бродифакума. РДЦ-препараты 2-го поколения на их основе (концентраты) согласно гигиенической классификации пестицидов по степени опасности при однократном пероральном воздействии относятся ко 2-му классу опасности (опасные соединения), при дермальном - к 3-4-му классам, оказывают слабо выраженное раздражающее действие на слизистые оболочки глаза, не обладают раздражающим действием на кожу, не оказывают сенсибилизирующего действия. С учетом сильно выраженного кумулятивного действия и кожно-резорбтивной токсичности концентрата относятся к 1-му классу опасности (чрезвычайно опасные соединения).

Готовые приманки постоянного состава (21 препарат) на основе бромадиолона и бродифакума при однократном пероральном и дермальном воздействии относятся к 4-му классу опасности (малоопасные соединения), оказывают слабовыраженное раздражающее действие на слизистые оболочки глаза, не обладают раздражающим действием на кожу, не оказывают сенсибилизирующего действия. С учетом сильно выраженного кумулятивного действия относятся ко 2-му классу опасности (опасные соединения). 
Д. Хенри и Х. Уазман (1998) отмечают, что даже одна доза суперварфаринов может вызвать признаки отравления с тяжелыми и сохраняющимися долгое время последствиями. По данным Mack R.B. (1994), коагулопатию, обусловленную дефицитом витамина К, может вызвать 1 мг суперварфарина. Суперварфарины в 100 раз сильнее в сравнении с варфарином - увеличение активности приводит к длительной коагулопатии продолжительностью от нескольких недель до нескольких месяцев [26].

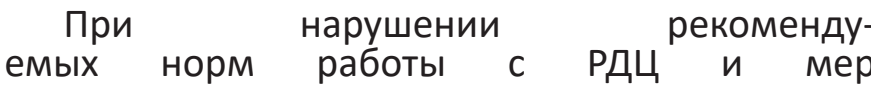
предосторожности при их использовании возможно развитие отравления, признаками которого являются геморрагический синдром (геморрагии на коже, носовые кровотечения, стул с примесью крови или "мелена», гематурия, кровохарканье), слабость, бледность, одышка, анорексия, рвота, синкопе, боль в животе. В большинстве описанных в зарубежной литературе случаев пациенты находились в контакте с РДЦ, применяемыми в домашних условиях, работая на заводах по производству РДЦ или контактируя непосредственно с РДЦ, содержащимися в других средствах [20, 48, 55, 34].

И.В. Колосова и соавт. (2012) привели два случая криминала - отравления родентицидами, связанные со служебной деятельностью. Поскольку период полужизни варфарина составляет 17 часов, назначение препаратов витамина К, и/или трансфузии СЗП позволяют скоррегировать МНO, а при отравлении суперварфаринами, имеющими период полужизни до 69 суток, после прекращения терапии витамином К, МНО снова удлиняется, что было отмечено у двух этих пациентов. Авторы отмечают значительное затруднение диагностики К-зависимой коагулопатии в случаях криминального характера и преимущество применения концентратов протромбинового комплекса в подобных ситуациях по сравнению с трансфузиями свежезамороженной плазмы.

Диагностика у пациента суперварфарин-индуцированной коагулопатии является сложной задачей, поскольку не всегда есть указания на контакт с отравляющим веществом (РДЦ), а начальные клинические проявления могут быть неспецифическими. При поступлении больного с коагулопатией неясной этиологии необходимо проводить дифференциальную диагностику с отравлением варфарином, ДВС-синдромом, тяжелой целиакией, сопровождающейся мальабсорбцией с дефицитом витамина К, с воздействием патологических ингибиторов коагуляции и т. д. [25]. К сожалению, определение в крови суперварфаринов возможно не в каждом даже крупном медицинском центре, поэтому Nelson А.T. et al. отмечают необходимость эмпирического введения высоких доз витамина К при подозрении на отравление РДЦ. Основная группа пострадавших от воздействия суперварфаринов - это дети до 19 лет. У взрослых отравления делятся на преднамеренные (попытка самоубийства или как представление имитируемого расстройства), случайные и неизвестные [45]. В большинстве случаев диагностируются незначительные нару- шения, определяемые как некоторые признаки или симптомы в результате воздействия яда, но быстро устраненные, без остаточной инвалидности; на втором месте по частоте диагностируются нарушения умеренной тяжести с более выраженными признаками и симптомами воздействия, потребовавшими той или иной формы лечения, но без наступления инвалидности; значительно реже встречаются серьезные последствия (опасные для жизни состояния или наступление инвалидности) и очень редко - смертельные исходы $[40,41,51,52,53]$.

Пострадавшего следует немедленно отстранить от контакта со средством, освободить от загрязнённой одежды, создать покой и тепло, срочно принять меры по удалению яда из организма. При случайном попадании средства в желудок пострадавшему следует немедленно выпить несколько стаканов воды или раствора марганцево-кислого калия (1:5000, 1:10000), затем вызвать рвоту, дать активированный уголь и солевое слабительное (20-25 г сульфата натрия в стакане воды). В качестве антидота при случайном отравлении применяют витамины К1 (фитоменадион), К3 (викасол). При попадании средства на кожу необходимо промыть ее тёплой водой с мылом. При попадании средства в глаза рекомендуется обильно промыть их водой или $2 \%$ раствором пищевой соды, после чего закапать 1-2 капли 30\% раствора сульфацила натрия (альбуцид).

Диагностика основывается на анамнезе описанных выше клинических симптомов, анализе крови (анемия, тромбоцитопения, гипопротеинемия, повышение щелочной фосфатазы, возможно умеренное повышение печеночных ферментов). Важное место в диагностике отравления кумаринами отводится коагулограмме, где выявляются увеличение международного нормированного отношения (МНО), протромбинового времени и активированного частичного тромбопластинового времени (АЧТВ), снижение уровней II, VII, IX и X факторов свертывания крови.

При проведении дифференциального диагноза между различными причинами снижения уровня прокоагулянтов II, VII, IX, X следует иметь в виду, что дефицит витамина К наблюдается при вытеснении витамина К из метаболизма факторов свертывания антикоагулянтами непрямого действия; недостаточном образовании в кишечнике и вследствие этого недостаточном поступлении в организм витамина К (К-авитаминоз при кишечном дисбактериозе медикаментозного генеза, чаще - при лечении антибиотиками); при энтеропатиях с профузными поносами; нарушении всасывания витамина $\mathrm{K}$ из-за нарушения поступления желчи в кишечник (механическая желтуха с ахолией); неонатальные формы, связанные с недоношенностью новорожденных и недостаточным синтезом в кишечнике витамина К; тяжелые поражения паренхимы печени (острые дистрофии, гепатиты, циррозы) [3, 5; 8, $9,14]$. Однако при заболеваниях печени наблюдается депрессия не только К-зависимых факторов, но и не зависящего от витамина К фактора V, учет динамики которого облегчает разграниче- 
ние печеночных и не печеночных форм геморрагического синдрома.

Терапия отравления непрямыми антикоагулянтами включает следующие действия $[5,7,8$, $9,18,53]$.

1. Немедленное прекращение контакта с антикоагулянтом.

2. Госпитализация в отделение реанимации без одежды не менее чем на 24 часа с запретом получения передач от родственников.

3. Переливание свежезамороженной плазмы или введение концентратов факторов протромбинового комплекса (КПК). Для коррекции гемостаза рекомендуется использовать трехфакторные КПК у больных с МНО ниже - 4, у больных с большим МНО следует отдавать предпочтение четырехфакторным КПК [43]. При выраженном анемическом синдроме - переливание эритроцитсодержащих средств.

4. Назначение витамина К. Лучше использовать $K_{1}$ (фитоменадион), а не $K_{3}$ (викасол). Если у больного нет активного кровотечения и нет необходимости срочной коррекции МНО, методом выбора является пероральное назначение витамина $\mathrm{K}_{1}$ в дозе 1 - 2 мг, при большом MHO пероральная доза может быть увеличена до 5 мг; для лечения массивного, угрожающего жизни кровотечения витамин $\mathrm{K}_{1}$ следует вводить в дозе 10 - 20 мг медленно; после внутривенного введения эффект наступает через 2 - 4 часа, максимальный эффект независимо от пути введения наступает через 24 часа [8, 9, 48, 54]. Показатели коагулограммы следует проверять до их полной нормализации. Иногда на это уходят недели или месяцы. Если недоступен К1, то можно назначить викасол.

Начало синтеза факторов свертываемости после введения препаратов витамина К варьирует от 6 до 12 часов, нормализация их содержания наступает через 3 - 5 дней, поэтому о трансфузии свежезамороженной плазмы или введения КПК, как источника факторов свертывания, забывать не стоит. Ряд авторов указывает, что в тяжелых случаях коагулопатии следует вводить препарат рекомбинантного фактора VIIa $[42,55]$.

Продолжительность поддерживающей терапии составляет для варфарина 15 дней, для РДЦ 2-го поколения или неизвестного вида - в среднем 1 месяц. Принятие решения о прекращении терапии должно быть комплексным и основываться на пробной отмене препарата по истечении 2-4 недель и учете контрольных анализов свертывающей системы крови через 36-48 и 96 часов после отмены [18].

\section{К-зависимая коагулопатия при механиче- ской желтухе}

Все виды механической желтухи, как и другие нарушения поступления желчи в кишечник, ведут к резкому ослаблению или прекращению всасывания витамина К и к неуклонно прогрессирующему дефициту факторов VII, X, II и IX. Лабораторно эта депрессия начинает четко вы- являться уже на 5-7 дни после полного прекращения поступления желчи в кишечник. Наклонность к кровотечениям становится заметной через 12-18 дней. Непосредственно механическая желтуха приводит к прогрессирующему поражению паренхимы печени, что на поздних этапах обусловливает дополнительное снижение уровня факторов V, VIII.

Подобная коагулопатия развивается у 7-39\% больных механической желтухой [12]. Первые кровотечения возникают обычно при удлинении протромбинового времени и/или МНО в 2,5-3 раза [12]. Бывают кровоизлияния на месте инъекций, в местах расчесов кожи, носовые, десневые и желудочно-кишечные кровотечения, кровь в моче. Возможны кровоизлияния в стенку кишечника, в брюшину, забрюшинную клетчатку, внутричерепные кровоизлияния.

Диагностика основывается на выявлении дефицита К-витаминзависимых факторов. В дальнейшем возможно присоединение дефицита остальных компонентов свертывающей системы крови, зависящих от функции печени, а также дисфункция тромбоцитов.

Лечение. Необходимы внутривенное введение достаточно больших доз препаратов витамина К и хирургическое восстановление желчеотделения в первые 3 недели желтухи. При необходимости ургентной коррекции гемокоагуляции назначают струйные трансфузии плазмы и введение концентратов протромбинового комплекса. При выраженной патологии печени и неэффективности препаратов витамина $\mathrm{K}$ дополнительно назначают соматотропин, который улучшает синтез факторов VII, II, X и IX.

Геморрагическая болезнь новорожденных или гипо-К-витаминзависимая транзиторная неонатальная коагулопатия

В течение первых 4- 7 дней после рождения наблюдается снижение концентрации факторов свертывания в плазме. Раннее кормление молозивом может значительно смягчить эту депрессию К-витаминзависимых факторов [12]. Одну из главных ролей в ликвидации рассматриваемого нарушения играет заселение кишечника ребенка нормальной микрофлорой, продуцирующей витамин К [12]. Благодаря этому к концу 2-й недели жизни дефицит К-витаминзависимых факторов у большинства детей полностью устраняется [12].

Чаще недостаточность К-витаминзависимых факторов у новорожденных не приводит к кровоточивости. Геморрагический синдром чаще встречается при недоношенности. Болезни матери и прием ею во время беременности препаратов, способствующих К-гиповитаминозу, а также акушерская патология (асфиксия плода, травматичные роды) способствуют развитию геморрагической болезни новорожденных [12]. Она усугубляется и энтеропатией новорожденных, назначением им антибиотиков при пневмонии, сепсисе и других заболеваниях. Регистрируется данная патология у 0,25 - 0,5\% новорожденных с частотой от 1:4000 до 1:2000 случаев [12]. 
Типичным проявлением заболевания является геморрагический синдром, возникающий между 2-м и 5-м днями жизни и затем исчезающий в течение 2-3 дней. Наиболее распространены желудочно-кишечные кровотечения. Нередко возникают также пупочные и носовые кровотечения, множественные кровоизлияния в кожу и подкожную клетчатку. При несвоевременном или недостаточном лечении количество летальных исходов достигает 30\%, причем почти все больные умирают в первые 2-3 дня после начала геморрагических явлений, а некоторые - в течение нескольких часов [12]. Летальный исход чаще связан с большой острой кровопотерей или с кровоизлияниями в мозг, реже - с кровотечениями во внутренние органы (почки, печень, миокард, надпочечники).

Характерные сроки развития патологического процесса, его частая связь с недоношенностью, наличие кровотечений у матери ребенка косвенно указывают на возможность развития геморрагической болезни новорожденных. Диагноз подтверждается выявлением нарушений в тестах, обусловленных дефицитом витамина К. Для установления правильного диагноза необходимо исключить другие виды кровоточивости, характерные для периода новорожденности: ДВС-синдром, наследственный дефицит отдельных факторов свертывания (особенно факторов V, VII и XIII, дающих выраженную кровоточивость у новорожденных), тромбоцитопении новорожденных.

Так как при гиповитаминозе К в печени страдает синтез двух физиологических антикоагулянтов - протеинов C и S - у новорожденных особенно высок риск сочетания геморрагического синдрома с тромбозами и ишемическими некрозами кончиков пальцев, ушей, кожи живота, груди и других мест [12]. Поэтому к внутривенным введениям КПК следует прибегать лишь по особым показаниям, поскольку они легко провоцируют у новорожденных опасные для жизни диссеминированное внутрисосудистое свертывание и тромбозы. В данной ситуации лучше использовать КПК, содержащие наряду с II, VII, IX, X факторами и протеин C, препятствующий развитию тромбозов (например протромплекс 600). В связи с тем, что данная патология зачастую имеет стремительное прогрессирование болезни, терапия должна иметь немедленный эффект. Это достигается переливанием свежезамороженной плазмы в дозе 10 - 15 мл/кг.

Одновременно внутривенно вводят препараты витамина К. Однако из-за высокого риска развития тромбозов в данной ситуации не следует назначать очень высокие дозы препаратов витамина К [12]. Профилактическая доза викасола не должна превышать 1 мг в день; лечебная его доза 3-5 мг в сутки, обязательно в комбинации с СЗП.

\section{Коагулопатия обусловленная кишечным дисбактериозом, энтеропатией}

Тяжелые и затяжные энтериты и энтеропатии могут вести к К-витаминной недостаточности и нарушению синтеза факторов VII, X, II и IX. B большинстве случаев этот дефицит не достигает критического уровня и остается субклиническим, реже - у детей в возрасте до 3 лет - возникает геморрагический синдром. Аналогичные нарушения наблюдаются при кишечном дисбактериозе, вызванном приемом внутрь антибиотиков, уничтожающих нормальную микрофлору кишечника; особенно неблагоприятно влияние препаратов тетрациклинового ряда и левомицетина (хлорамфеникола).

В большинстве случаев у больных на коже появляются мелкие кровоизлияния, возникают носовые, десневые и кишечные кровотечения. Кишечные кровотечения долго могут быть скрытыми, проявляясь только нарастающей анемизацией больного. Диагностика этой коагулопатии проводится по тем же принципам, что и при других формах дефицита ватамина К.

Основной метод лечения: внутривенное или внутримышечное введение препаратов витамина К, отмена антибиотиков и других антибактериальных препаратов, назначение ферментных и бактериальных препаратов. В наиболее тяжелых случаях, сопровождающихся энтеропатической гипопротеинемией, применяют переливание плазмы, введение альбумина и электролитных растворов. При тяжелом геморрагическом синдроме, который в данной ситуации встречается крайне редко, используют концентраты протромбинового комплекса.

\section{Коагулопатия при заболеваниях печени}

Коагулопатия при заболеваниях печени возникает в результате множественных нарушений гемостаза. На фоне внутрипеченочного холестаза ухудшается утилизация витамина К, снижается синтез витамин-К-зависимых факторов (II, VII, IX и X) и не зависящих от витамина К факторов - V, XI, XII, XIII, фибриногена. Наблюдается хроническая активация свертывания и фибринолиза. Развивается дисфункция тромбоцитов и снижение их числа. Ускоряется фибринолиз за счет повышенного уровня тканевого активатора плазминогена и снижения содержания ингибиторов активатора плазминогена и $\alpha 2$-антиплазмина. При тяжелом поражении гепатоцитов некротизированными клетками выделяется тканевой фактор, ФНО, ИЛ-1, эндотоксины. В результате этих процессов образуется тромбин и плазмин в микроциркуляторном русле, способствуя развитию тяжелого нарушения гемостаза - ДВС-синдрома.

Лабораторные показатели: пролонгировано ПВ, несколько увеличено АПТВ, снижены тромбоциты, низкий уровень фибриногена, высокий уровень ПДФ. Уменьшено содержание витамин-К-зависимых факторов и факторов V, XI, XII, XIII, фибриногена. Уровень плазминогена снижен, АT-III, протеин C, протеин S, $\alpha 2$-антиплазмин снижен, ингибитор активатора плазминогена и а2-макроглобулин повышены.

Необходимо отметить, что у подавляющего большинства пациентов коагулопатия развивается на фоне развернутой клинической картины гепатита, цирроза или другого поражения печени. Поэтому тщательное клиническое обследование пациента уже позволит правильно определить характер коагулопатии и назначить необходи- 
мый комплекс лабораторных исследований.

Лечение коагулопатии при патологии печени

1.Коррекция дефицита витамина К: введение СЗП (6 - 8 доз), при массивном кровотечении каждые 6 - 12 часов; введение тромбомассы, концентратов АT - III, десмопрессина при нарушенной функции тромбоцитов.

2.С целью купирования острой печеночной недостаточности назначаются глюкокортикоиды, гепатопротекторы, иммуноглобулины.

3. Введение концентратов протромбинового комплекса нежелательно и опасно, т.к. они могут усугубить ДВС-синдром и вызвать тромбоцитопенические осложнения [2].

\section{Концентраты протромбинового комплекса}

Исходно концентраты протромбинового комплекса (КПК) были созданы как источник FIX и использовались в 1970 - 1980-х годах для лечения больных гемофилией В. В зависимости от состава различают исторически более старые трехфакторные КПК, в состав которых входят FII, FIX, FX, и четырехфакторные КПК, содержащие, кроме уже названных, еще и FVII. Однако КПК для лечения больных гемофилией В оказались менее эффективными, чем концентрат FIX, и в настоящее время для лечения этой категории больных КПК почти не используют.

КПК получают из больших пулов плазмы с помощью ионообменной хроматографии. Материалом, используемым для его выделения, обычно является супернатант, остающийся после осаждения криопреципитата, или супернатант плазмы с удаленным из него антитромбином и FXI. С помощью сильных ионообменников получают четырехфакторные КПК, с помощью слабых ионообменников - трехфакторные КПК.

Важной проблемой при изготовлении препаратов из плазмы крови остается обеспечение их вирусной безопасности. Вирусная безопасность КПК достигается отбором доноров, скринингом индивидуальных донорских образцов и пулов плазмы с целью выявления специфических маркеров инфекции, а также использованием при производстве эффективных процессов инактивации/удаления вирусов. Несмотря на это, при применении лекарственных препаратов, полученных из крови или плазмы человека, передача инфекционного агента не может быть полностью исключена. Это так же применимо к неизвестным или новым вирусам и другим патогенным возбудителям. Принимаемые меры считаются эффективными в отношении оболочечных вирусов, таких как ВИЧ-1/2, вирусов гепатитов В и С и безоболочечного вируса гепатита А. Применяемые технологии удаления/инактивации могут быть недостаточно эффективны в отношении некоторых безоболочечных вирусов, например, таких, как парвовирус В19.

Другая немаловажная проблема при использовании КПК - это тромбогенность. Изначально КПК, предназначенные для лечения больных гемофилией В, были весьма тромбогенны [30;
35]. Можно выделить 3 группы факторов риска тромботических осложнений при использовании КПК: обусловленные состоянием пациента, проводимой сопутствующей терапией, обусловленные самими КПК [28]. Риск тромботических осложнений после применения КПК может быть снижен назначением больному гепарина или концентрата антитромбина III. В современных КПК снижено, по сравнению с другими факторами, содержание FII. Уменьшает тромбогенность современных КПК и добавление в их состав антикоагулянтов. Показано, что добавление в состав КПК гепарина и антитромбина позволяет полностью нейтрализовать потенциальный тромбогенный эффект, вызываемый генерацией FIXa и FXa [46]. По другим данным, число тромботических осложнений после применения современных КПК составило всего 7 (1,4\%,) на 506 случаев их применения [44].

При применении концентратов факторов протромбинового комплекса существует риск развития реакций повышенной чувствительности, включая анафилактические реакции и анафилактический шок. При проведении заместительной терапии концентратом факторов протромбинового комплекса возможна выработка циркулирующих антител, ингибирующих один или несколько факторов свертывания. Появление ингибиторов выражается в виде недостаточного клинического ответа.

Дискутируется вопрос, какие КПК лучше использовать - трехфакторные (Prothrombinex HT, Bebulin, Preconativ) или четырехфакторHble (Prothromplex ${ }^{\circledR}$ 600, Beriplex ${ }^{\circledR}$, Kaskadil ${ }^{\circledR}$, Octaplex ${ }^{\circledR}$, Cofact $\left.^{\circledR}\right)$. Для коррекции гемостаза y больных с МНО ниже - 4 рекомендуется использовать трехфакторные КПК, у больных с большим МНО следует отдавать предпочтение четырехфакторным КПК.

Существуют различные схемы назначения КПК при дефиците витамин К-зависимых факторов.

1. С помощью протромбина по Квику. Протромбиновый индекс и активность протромбина по Квику могут совпадать друг с другом в области нормальных значений, однако расходятся в зоне низких значений. Формула расчета дозы КПК с использованием протромбина по Квику: (ПК целевой - ПК исходный) х масса тела (кг) = Доза КПК (МЕ), где ПК - протромбин по Квику, \%. Например, если у больного массой тела 70 кг и протромбином по Квику 15\% необходимо достичь протромбин по Квику 50\%, доза КПК составит: $(50 \%-15 \%)$ x 70 кг = $2450 \mathrm{ME}$.

2. Расчет дозы можно провести по МHO, пересчитанному в процент протромбинового комплекса. «Процентный» метод основан на допущении, что 1 мл нормальной плазмы содержит 1 ед. каждого из коагуляционных факторов, и что протромбиновый комплекс, выраженный в \% от нормальной плазмы, соответствует среднему уровню витамин К-зависимых факторов свертывания крови.

Для расчета дозы КПК целевое и имеющееся у больного МНО пересчитывается в \% протром- 


$$
\begin{gathered}
2,0-3,9 \\
4,0-5,9 \\
\geq 6,0
\end{gathered}
$$

$25 \mathrm{ME} / \mathrm{Kr}$

$35 \mathrm{ME} / \mathrm{Kr}$

$50 \mathrm{ME} / \mathrm{Kr}$ бинового комплекса (ПК), и доза препарата рассчитывается по формуле: (ПК целевой - ПК исходный х масса тела (кг), где доза КПК (ME), где ПК - протромбиновый комплекс, \%. Например, если у больного массой тела 80 кг МНО 7 и надо достичь МНО 1,5, то доза КПК составит: (40\% 5\%) $\times 80 \mathrm{kr}=2800 \mathrm{ME}$.

Метод расчета дозы КПК с учетом исходного МНО и массы тела больного. При таком подходе полная реверсия действия варфарина достигается в 83\% случаев [31]. В большинстве случаев независимо от величины МНО купировать геморрагический синдром помогает доза $30 \mathrm{ME} /$ кг массы тела. У пожилых больных часто бывает достаточной доза 500 ME KПK (Imberti D., et al., 2009). В то же время показано, что лечение, проводимое с применением индивидуально рассчитанной дозы, более эффективно, чем с помощью стандартной дозы [46].

При назначении КПК пациентам с изолированным дефицитом одного из факторов протромбинового комплекса дозы рассчитывают для каждого пациента индивидуально, интервалы между введениями устанавливают в зависимости от значения периода полувыведения дефицитного фактора.

\section{Формулы расчета необходимой дозы}

FII: доза (ME) = масса тела (кг) $x$ желаемое повышение фактора (\%) x 0,5;

FVII: доза (ME) = масса тела (кг) $\mathrm{x}$ желаемое повышение фактора (\%) х 0,6;

FIX: доза (ME) = масса тела (кг) $\mathrm{x}$ желаемое повышение фактора (\%) х 1,2;

FX: доза (ME) = масса тела (кг) $\mathrm{x}$ желаемое повышение фактора (\%) х 0,6.

Современным КПК, наиболее активно использующимся в настоящее время в России, является Протромплекс 600. Он содержит факторы свертывания крови II (600 ME), VII (500 ME), IX (600 ME), X (600 ME), протеин C (не менее 400 ME). Вспомогательные вещества: натрия цитрата дигидрат - 80 мг, натрия хлорид - 160 мг, гепарин натрия - не более 0,5 ME гепарина/ME фактора IX, антитромбин III - от 15 до 30 ME.

Разовую дозу и частоту введения устанавливают индивидуально с учетом исходных показателей системы свертывания, локализации и выраженности кровотечения, клинического состояния пациента. При назначении пациентам с приобретенным дефицитом факторов протром- бинового комплекса, в частности, для лечения и профилактики кровотечений при передозировке непрямых антикоагулянтов - антагонистов витамина К, при расчете дозы следует ориентироваться на значение либо протромбина по Квику, либо МНО в зависимости от того, какой показатель определяет лаборатория. Если ориентироваться на значение протромбина по Квику, следует исходить из допущения, что $1 \mathrm{ME}$ препарата на 1 кг массы тела повышает значение протромбина примерно на 1\%. Если же учитывать исходное значение МНО, то расчет дозы проводят следующим образом (таблица 1).

Целью лечения является достижение значения МНO 1,0 - 1,2; иногда до 1,5, в зависимости от клинической ситуации. Вопрос о введении повторной дозы препарата следует решать индивидуально с учетом динамики клинического состояния пациента, сопутствующей терапии и достигнутого значения МНО.

При назначении пациентам с врожденным изолированным дефицитом одного из факторов протромбинового комплекса разовую дозу рассчитывают для каждого пациента индивидуально (см. формулы расчета необходимой дозы), а интервалы между введениями устанавливают в зависимости от значения $\mathrm{T}_{1 / 2}$ дефицитного фактора. При в/в введении препарата происходит повышение концентрации в плазме крови всех четырех факторов свертывания, зависящее от величины введенной дозы. В ходе последующего потребления концентрации факторов в плазме постепенно снижаются. Самый короткий $\mathrm{T}_{1 / 2}$ имеет фактор II - 40-60 ч, T $1 / 2$ фактора VII - 3-5 ч, фактора IX - 16-30 ч, фактора X - 30-60 ч.

При применении данного концентрата факторов протромбинового комплекса осложнения, описанные выше, встречаются крайне редко.

Таким образом, в настоящее время диагностика большинства приобретенных К-витаминзависимых коагулопатий доступна в реальных клинических условиях. Своевременная диагностика варианта коагулопатии и назначение адекватной терапии в большинстве случаев способствуют благоприятному сходу.

\section{Литература}

1. Баркаган 3.С., Момот А.П. Диагностика и контролируемая терапия нарушений гемостаза. M., 2001. 296 c.

2. Баркаган 3.С. Приобретенные геморрагические коагулопатии // Руководство по гематоло- 
гии / под ред. А. И. Воробьева, изд. третье в 3-х т. Т. 3, М.: Ньюдиамед, 2005. С. $82-90$.

3. Белоусов Ю.Б., Кукес В.Г., Лепахин В.К., Петров В.И. Клиническая фармакология. Национальное руководство. М.: ГЭОТАР-Медиа. 2009. 965 c.

4. Бокарев И.Н., Попова Л.В., Козлова Т.В. Тромбозы и противотромботическая терапия в клинической практике. М.: МИА. 2009. 511 с.

5. Васильев С.А., Виноградов В.Л., Гемджян Э.Г. Проблема геморрагического синдрома при лечении антагонистами витамина К // Терапевтический архив. 2012. №7. С. $89-93$.

6. Войцеховский, В.В., Ландышев Ю.С., Гоборов Н.Д. Случай диагностики варфаринового некроза кожи // Новые Санкт-Петербургские врачебные ведомости. 2012. № 2. С. 86 -91.

\section{7. Войцеховский}

ник А.В., Битюцкая

B.B.,

Пив-

Л.Г., Процко Т.Т. вслеб факум "Щелкунчик» // Терапевтический архив. 2012. № 7. С. $66-71$.

8. Галстян Г.М. Нарушения гемостаза, обусловленные дефицитом витамин К-зависимых факторов свертывания крови - патогенез, способы коррекции и рекомендации по лечению // Гематология и трансфузиология. 2012. №2. С. 7 -21 .

9. Галстян Г.М. Применение концентратов протромбинового комплекса по утвержденным и неутвержденным показаниям: новые перспективы старых препаратов // Гематология и трансфузиология. 2018. Т. 63. № 1. С. 78-91.

10. Денисенко В.И. Гигиеническое обоснование безопасного производства и применения современных родентицидных средств - антикоагулянтов на основе бромадиолона и бродифакума. Автореф. дис. канд. мед. наук. Москва. 2008. 25 c.

11. Колосова И.В., Галстян Г.М., Орел Е.Б. и др. Терапия геморрагического синдрома, вызванного дефицитом витамин К-зависимых факторов свертывания крови. Гематология и трансфузиология. 2012. № 2. С. $22-30$.

12. Кузник Б.И., Стуров В.Г., Максимова О.Г. Геморрагические и тромботические заболевания и синдромы у детей. Новосибирск: Наука. 2012. 455 с.

13. Мамаев Н.Н., Рябов С.И. Гематология. СПб.: СпеџЛит, 2008. 543 с.

14. Момот А.П. Патология гемостаза. Принципы и алгоритмы клинико-лабораторной диагностики. СПб.: ФормаТ. 2006. 207 с.

15. Момот А.П. Современные методы распознавания состояния тромботической готовности. Барнаул. Издательство Алтайского государственного университета. 2011. 138 с.

16. Проведение экстренных мероприятий по дезинсекции и дератизации в природных очагах чумы на территории Российской Федерации. Методические указания. Москва. 2009. 85 с.
17. Стойко Ю.М., Замятин М.Н. Современные возможности профилактики тромбоэмболических осложнении у пациентов с высоким и очень высоким риском // Хирургия. Приложение к журналу Consilium medicum. 2007. №2. С. $40-43$.

18. Хенри Д.А., Уайзман Х.М. Профилактика и лечение отравлений. Перевод с английского. М.: «Медицина». 1998. 339 с.

19. Чарная М.А., Морозов Ю.А. Тромбозы в клинической практике. М.: ГЭОТАР-Медиа. 2009. 214 c.

20. Abell T.L., Merigian K.S., Lee J.M., et al. Cutaneous exposure to-like anticoagulant warfarin causing an intracerebral hemorrhage: a case report. J Toxicol Clin Toxicol.1994;32: 69-73.

21. Ageno W., Crowther M., Steidl L et al. Low dose oral vitamin $\mathrm{K}$ to reverse acenocoumarolinduced coagulopathy: a randomized controlled trial. Tromb. Haemost. 2002; 88: 48-51.

22. Bye, A., King, H. K. The biosynthesis of 4-hydroxycoumarin and dicoumarol by Aspergillus fumigatus Fresenius. Biochemical Journal 1970. $117,237-245$.

23. Chan YC, Valenti D, Mansfield AO, Stansby G (2000). Warfarin induced skin necrosis. Br J Surg 87 (3): $266-72$.

24. Chua J.D., Friedenberg W.R. Superwarfarin poisoning. Archives of internal medicine. 1998 Sep 28 ; 158(17): $1929-32$.

25. Corke PJ. Superwarfarin (brodifacoum) poisoning. Anaesth Intensive Care.1997;25: 707 709.

26. Dam H. Cholesterinstoffwechsel in Huhnereiern und Huhnchen. Biochem. Z.1929; 215: $475-481$.

27. Dam H. The antihemorrhagic vitamin of the chick. Occurrence and chemical nature, Nature, 1935; 135: 652.

28. Demeyere R., Gillardin S., Arnout J., Stengers P.F. Comparison of fresh frozen plasma and protrombin complex concentrate for the reversal of oral anticoagulants in patients undergoing cardiopulmonary bypass surgery: a randomized study. Vox Sang. 2010; 99: 251- 260.

29. Hambleton J., Wages D., Radu- Radulescu L. et al Pharmacokinetic study of FFP Photochemically treated with amotosalen and UV light compared to FFPin healthy volunteers anticoagulated with warfarin. Transfusion 2002; 42:1302 - 1307.

30. Hellstern P., Beeck H., Fellhauer A., et al Prothrombin complex concentrates. Vox Sang. 1997; 73 : $155-161$.

31. Holland L.L., Brooks J.P Toward rational fresh frozen plasma transfusion: The effect of plasma transfusion on coagulation tests results. Am J.Clin. Patrol. 2006: 126: 133 - 139.

32. Holland L, Warkentin T.E, Refaai M. et al Suboptimal effect tree-factor prothrombin complex concentrate in correcting supratheurapeutic international normalized ratio due to warfarin 
overdose. Transfusion 2009; 49: 1171 - 1177.

33. Huic M., Francetic I., Bakran I. et al. Acquired coagulopathy due to anticoagulant rodenticide poisoning. Croat Med J. 2002 Oct;43(5):615-7.

34. Gunja N., Coggins A., Bidny S., Management of international superwarfarin poisoning With long term vitamin $\mathrm{K}$ and brodifacoum levels. Clin. Toxicol. 2011; 49: 385 - 390.

35. Josik D., Hoffer Buchacher A., et al Manufacturing of a prothrombin complex concentrate aiming at low trombogenicity. Thromb. Res. 2000.

36. Kohler M. Trombogenicity of protrombin complex concentrates. Thromb. Res. 1999.

37. Kruse J.A., Carlson R.W. Fatal poisoning with rodenticide brodifacoum. Annals of emergency medicine.. 1992 Mar; 21 (3): 331 - 6.

38. Lee S.B, Manno E.M., Layton K.F., Wijdicks E.F. Progression of warfarin -associated intracerebral hemorrhage after INR normalization with FFP. Neurology 2006; 67: 1272 - 1274.

39. Link K.P. The discovery of dicumarol and its sequels. Circulation. 1959. 19(1): $97-107$.

40. Litovitz TL, Klein-Schwartz W, White S, et al. 2000 annual report of the American Association of Poison Control Centers, Toxic Exposure Surveillance System. Am J Emerg Med. 2001; 19: 337 - 395.

41. Litovitz TL, Klein-Schwartz W, Rodgers GC, Jr., et al. 2001 annual report of the American Association of Poison Control Centers, Toxic Exposure Surveillance System. Am J Emerg Med. 2002; 20: $391-452$.

42. Logan A.C., Yank V., Stafford R.S. Off- label use of recombinant factor VII a in US hospitals: Analisis of hospital records. Ann. Intern.Med. 2011; 154: $516-522$.

43. Markis M. Watson H.G. The management of coumarin- induced over-anticoagulation $\mathrm{Br}$. J Haemotol. 2001; 114; $271-280$.

44. Marietta M., Pedrazzi P., Luppi M., Tree of four factor prothrombin complex concentrate for emergency anticoagulation reversal: what are we really looking for. Blood Transfus. 2011; 9:469.

45. Nelson A.T., Hartzell J.D., More K., Durning S.J. Ingestion of superwarfarin leading to coagulopathy: a case report and review of the literature. MedGenMed. 2006; 8(4): 41.

46. Pabinger I, Tiede A., Kalina U. et al impact of infusion speed on the safety and effectiveness of protrombin complex concentrate. Ann. Hematol. 2010; 89: $309-316$.

47. Park BK, Choonara IA, Haynes BP, et al. Abnormal vitamin $\mathrm{K}$ metabolism in the presence of normal clotting factor activity in factory workers exposed to 4-hydroxycoumarins. Br J Clin Pharmacol. 1986; 21: $289-293$.

48. Raj G., Kumar R., McKinney W.P. Time course of reversal of anticoagulant effect of warfarin by Intravenous and subcutaneous phytonadione Arch. Intern. Med. 1999; 159: 2721 - 2724.
49. Schofield F.W. Damaged sweet clover; the cause of a new disease in cattle simulating haemorrhagic septicemia and blackleg. J Am Vet Med Ass 1924 64: $553-6$.

50. Spahr J.E., Maul J.S., Rodgers J.M Superwarfarin poisoning: a report of two cases and review of literature. Am. J Haemotol. 2007;82: 656660.

51. Watson H.G., Baglin T., Laidlaw S.L et al. A comparison of the efficacy and rate response to oral and intravenous vitamin $\mathrm{K}$ in reversal of overanticoagulation with warfarin. Br. J Haemotol. 2001; $115 ; 145-149$.

52. Watson W.A., Litovitz T.L., Rodgers G.C., et al. 2002 annual report of the American Association of Poison Control Centers, Toxic Exposure Surveillance System. Am J Emerg Med. 2003; 21: 353 - 421.

53. Wojciechowski V.V., Calina D., Tsarouhas K., Pivnik A.V., Sergievich A.A., Kodintsev V.V., Filatova E.A., Ozcagli E.,, Docea A.O., Gofita E., Arsene A.L., Tsitsimpikou C., Tsatsakis A.M., Golokhvast K.S. $A$ guide to acquired vitamin $k$ coagulophathy diagnosis and treatment: the Russian perspective // DARU Journal of Pharmaceutical Sciences. 2017. T. 25. № 1. C. 10.

54. Yiu K.H, Siu C.W., Jim M.H., et al Compration of the efficacy and safety profiles of intravenous vitamin $\mathrm{K}$ and fresh frozen plasma as treatment of warfarin -related over anticoagulation in patients with mechanical heart valves. Am. J. Cardiol. 2006; 97: $409-411$

55. Zupancic-Salek S., Kovacevic-Metelko J., Radman I. Successful reversal of effect of anticoagulant superwarfarin poisoning with recombinant activated factor VII. Blood Coagul Fibrinolysis. 2005; 16: $239-44$.

Статья поступила в редакцию 12.01.2019

\section{Координаты для связи}

Войцеховский Валерий Владимирович, д.м.н., профессор, заведующий кафедрой госпитальной терапии с курсом фармакологии ФГБОУ ВО Амурская ГМА Минздрава России. E-mail: voitsehovsckij@yandex.ru

Заболотских Татьяна Владимировна, д. м. н., профессор, ректор ФГБОУ ВО Амурская ГМА Минздрава России.

Целуйко Сергей Семенович, д. м. н., профессор, проректор по научной работе ФГБОУ ВО Амурская ГМА Минздрава России, зав. кафедрой гистологии и биологии ФГБОУ ВО Амурская ГМА Минздрава России.

Почтовый адрес ФГБОУ ВО Амурская ГМА Минздрава России: 675006 Амурская область, г. Благовещенск, ул. Горького, д. 95. E-mail: AmurSMA@AmurSMA.su, science.dep@ AmurSMA.su 